\title{
De callcenterbranche in de Nederlandse arbeidsmarkt en arbeidsverhoudingen
}

Citation for published version (APA):

de Grip, A., Sieben, I. J. P., \& van Jaarsveld, D. (2006). De callcenterbranche in de Nederlandse arbeidsmarkt en arbeidsverhoudingen. Tijdschrift voor Arbeidsvraagstukken, 22(1), 71-83.

Document status and date:

Published: 01/01/2006

Document Version:

Publisher's PDF, also known as Version of record

\section{Please check the document version of this publication:}

- A submitted manuscript is the version of the article upon submission and before peer-review. There can be important differences between the submitted version and the official published version of record.

People interested in the research are advised to contact the author for the final version of the publication, or visit the DOI to the publisher's website.

- The final author version and the galley proof are versions of the publication after peer review.

- The final published version features the final layout of the paper including the volume, issue and page numbers.

Link to publication

\footnotetext{
General rights rights.

- You may freely distribute the URL identifying the publication in the public portal. please follow below link for the End User Agreement:

www.umlib.nl/taverne-license

Take down policy

If you believe that this document breaches copyright please contact us at:

repository@maastrichtuniversity.nl

providing details and we will investigate your claim.
}

Copyright and moral rights for the publications made accessible in the public portal are retained by the authors and/or other copyright owners and it is a condition of accessing publications that users recognise and abide by the legal requirements associated with these

- Users may download and print one copy of any publication from the public portal for the purpose of private study or research.

- You may not further distribute the material or use it for any profit-making activity or commercial gain

If the publication is distributed under the terms of Article $25 \mathrm{fa}$ of the Dutch Copyright Act, indicated by the "Taverne" license above, 


\title{
De callcenterbranche in de Nederlandse arbeidsmarkt en arbeidsverhoudingen
}

\author{
Andries de Grip, Inge Sieben en Danielle Van Jaarsveld*
}

In deze bijdrage onderzoeken we of er in Nederland sprake is van een gesegmenteerde arbeidsmarkt woor callcentermedewerkers (agents"). Ook gaan we na welke rol de flexibiliteitbehoefte die veel callcenters hebben hierbij speelt en in hoeverre de arbeidsmarktsegmentatie verankerd is in de Nederlandse arbeidswerhoudingen. De uitkomsten van een enquête onder callcentermanagers en kwalitatieve informatie uit een aantal casestudies laten zien dat de arbeidsmarkt voor callcentermedewerkers getypeerd kan worden als een secundaire arbeidsmarkt. Birnen dit secundaire segment is er sprake van een verdere segmentatie tussen inhouse callcenters, waar de relatief betere banen worden aangeboden en de facilitaire callcenters, waar de arbeidsvoorwaarden voor de medewerkers slechter zijn. Deze segmentatie is duidelijk gerelateerd aan de flexibiliteitbehoefte van de callcenters. Het duale karakter van de arbeidsmarkt voor callcentermedewerkers is terug te vinden in de arbeidswerhoudingen. Werknemers die werken in een inhouse callcenter vallen onder de bedrijfs- of bedrijfstak-CAO waaronder hun bedrijf ressorteent, tenwijl de facilitajre callcenters een nieuwe bedrijfsector met een eigen CAO zijn gaan vormen. Deze regulering van de arbeidsverhoudingen is - in vergelijking met andere landen - umiek, maar de recentelijk afgesloten tweede CAO tussen de werkgeversorganisatie en een branchegerichte werkmemersorganisatie laat zien dat CAO-vorming in een nieuwe branche waar het personeel werkzaam is in het lagere deel van een secundaire arbeidsmarkt ook zijn weerslag kan hebben op de Nederlandse arbeidsverhoudingen.

Trefwoorden: callcenters, arbeidsmarktsegmentatie, flexibiliteit, arbeidsverhoudingen

\section{Inleiding}

Evenals in veel andere landen is de werkgelegenheid in de Nederlandse callcenterbranche de afgelopen jaren sterk gegroeid. Volgens een. meting van Datamonitor (2002) waren er in Nederland in 20011.266 callcenters. Naar verwachting stijgt dit aantal tot bijna $2.000 \mathrm{in}$ 2006. Naar schatting werken er momenteel circa 188.000 mensen in deze sector, ofwel 2,5 procent van de totale beroepsbewolling (NFIA, 2004). Daarbij kan een onderscheid gemaakt worden tussen de "inhouse" callcen. ters, die een onderdeel vormen van een het bedrijf waarvoor ze de klantcontacten verzorgen $_{r}$ en de 'facilitaire' callcenters, die de klantcontacten van andere bedrijwen of instel- lingen verzorgen. In Nederland hebben inhouse callcenters het grootste aandeel op de callcentermarkt (Braaksma, 1998).

De callcenterbranche kenmerkt zich door het grote aantal werkenden dat is aangesteld op basis van zogenaamde 'atypische' arbeidscontracten (De Grip et al., 1997). Dit geldt met name voor de agents die de feitelijke klantcontacten verzorgen /Sieben \& De Grip, 20031. Zij hebben raak te maken met tijdelijke aanstellingen, deeltijdcontracten, onregelmatige diensten, oproepcontracten, en dergelijke. Het gebruil van deze atypische contracten hangt sterk samen met de grote behoefte aan flexibiliteit bij de inzet van call. centerpersoneel. Deze flexibiliteit is nodig

* Andries de Grip en Inge Sieben zijn werkzaam bij het Researchcentrum woor Onderwijs en Arbeidsmarkt (ROA), Universiteit Maastricht. Danielle Van Jaarsveld is werkzaam bij de Sauder School of Business, University of British Collumbia, Vancouver, Canada; Correspondentieadres: Andries de Grip. Researchcentrum voor Onderwijs en Arbeidsmarkt (ROA), Postbus 616, 6200 MD Maastricht, e-mail: a.degrip@roa.unimaas.nl. 
om pieken en dalen in de omvang wan het gegprekKenvolume op te wang Dramant is er in veel callcenters een sterke nadruk op kogtenbespuringen, wardoor er weinigin het personel word gelnvesteerd. Callcenters worden in dit werband nogal exs getyperd als "electonic swershops dic slechts "deadend jobs" anbueden IDery 8 Kinne, 2004 .

De arbed dsmante voor callcentermedewerkers zou darom hunnen worden gekarakteriseerd als en 'secundale albeidsmarkt' van onzekere, slecht betalde banen met weinig loopbanmogelikheden (zie bijvoorbeeld Dekker et 1., 1996). In het algemeen hebben de agents die wakzam zin in een inhouse call. center echrer betex arbeidsvoorwarden dan degenen die bij en facilitair callcenter werken. Dit kont doordat de medewerkers (agents) in inthouse callcenters meestal wallen onder de CAO van het bedrif warvan het betreffende callcenter deel uHtmakt. De faci. Htaire callcenters kregen echter pas in 2003 hum eerste $C A O$. Dit roept de wrag op in hoe. verre de arbeidsmarkt woor callcentermedewerkers getypeerd zou kunnen worden als een duale arbeidsmarkt, met een secundair segment biy de lacilitaire callcenters en een primair segment in de vorm van een 'vakdeelmarkt' bij de inhouse callcenters |zie bijvoorbeeld wan Hool \& Dronkers, 1980 \%.

In deze bijdrage willen we dan ook de arbeidsmark voor callcentermedewerkers bestuderen en nagaan in hoeverre er sprake is wan een secundaire arbeidsmarkt, of wan cen verder gesegmenteerde, duale arbeidsmarkt. Daarnalast willen we onderzoeken of de genoemde flexibiliteitbehoefte een verklaring kan bieden voor de arbeidsmarktsegmentatie in de callcentersector willen we nagan hoe deze segmentatie verankerd is in de Nederlandse arbeidsverhoudingen.

De verdere opzet van deze bijdrage is als volgt. Na een overzicht van de arbeidsmarktsegmentatietheorie volgt een bespreking van de onderzocksopzet en wordt een beeld geschetst van de Nederlandse callcentersector en het personeel dat hier werkzaam is. Dauma wordt onderzocht op welke punten er verschillen zijn tussen inhouse callcenters en facilitaire calleenters en of op grond daarvan gesproken kan wotden wan een gesegmenteer. de arbeidsmarkt. Verwolgens wordt bekeken in hoeverre de behoefte an flexibihiteit die bij veel callcenters leeft, een rol speelt in deze segmentatie. Ten slotte worden de arbeidsverhoudingen in de callcenterbranche in kaart gebracht en wordt er ragegaan of deze de aubeidsmarktsegmentatie reflecteren.

\section{De arbeidsmarktsegmentatietheorie}

In de arbeidsmarktsegmentatietheorie fzie bijwoorbeeld Doeringet \& Piore, 1971) worden in eerste instantie twee segmenten op de arbeidsmarkt onderscheiden, met enerzijds de betere, vaste, goed betalde banen met promotievooruitzichten ('primaire segment') en anderzijds de tijdelike, slecht betaalde banen zonder enige promotievooruitzichten ("secundaire segment" . Men spreekt dan wel van een 'dubbele" of "duale' arbeidsmarkt. Binnen het primaire segment van de arbeidsmarkt wordt er echter vaak een onderscheid gemalkt wussen (bedrifts)inteme arbeidsmarkten en vak. deelmarkten (van Hoof \& Dronkers, 1980 ; Osterman, 1982 . Interne arbeidsmarkten doen zich woor binnen grote bedrijen die een goed geschoold personeelsbestand willen opbouwen, waarbij ze hun interne arbeids. markt afschermen tegen de externe arbeidsmarkt. Vakdeelmarkten zijn daarentegen externe arbeidsmarktsegmenten woor wakspecifiek geschoolde beroepsgroepen die in verschillende bedrijven productief kunnen worden ingezet (zie bijwoorbeeld Dekker et al., 19961. Deze opsplitsing van het primaire segment wan de arbeidsmarkt in interne arbeldsmarkten en vakdeelmarkten had mede als doel het secundaire segment van de arbeidsmarkt beter te kunnen definiëren. Degenen die op dit segment van de arbeidsmarkt werkzaam zijn, hebben een losse band met de arbeidsmarkt. Ze hebben geen duurzame binding met een bepaald bedrijf, maar ook geen dunrzame binding met een bepaald beroep of vak. Een belangriik kenmerk van een secun. daire arbeidsmarkt is dan ook het hoge personeelsverloop (Bergeijk \& De Grip, 1985). Door het ontbreker van een duurzame binding met een bepaald bedrijf of beroep investeren zowel de werkgever als de werkenden zelf zo min mogelijk in aanvullende scholing, al maken 
Dekker, De Grip en Heijke (2002) hierbij de kanttekening dat het secundaire segment van de arbeidsmarkt soms wel een voorsorteertraject wan een interne arbeidsmarkt kan zijn. Al met al kunnen uit de segmentatieliteratuur de volgende kenmerken van een secundaire arbeidsmarkt worden gedestilleerd (zie ook van Hoof \& Dronkers, 1980 en De Grip, 1987): - een lage beloning;

- slechte secundaire arbeidsvoorwaarden;

- slechte arbeidsomstandigheden;

- weinig aanvullende scholing;

- veel tijdelijke contracten;

- veel deeltijdwerk;

- weinig doorgroeimogelijkheden; ${ }^{1}$

- een hoog personeelsverloop.

\section{Van Hoof \& Dronkers (1980) en De Grip} (1987) noemen behalve bovenstaande kenmerken het relatief lage opleidingsniveau van de werkenden als een kenmerk van de secundaire arbeidsmarkt. Dekker en anderen (1996; 2002) laten echter zien dat het karakter van de secundaire arbeidsmarkt op dit punt is veranderd. Ook mensen met een middelbare of hogere opleiding kunnen, al dan niet tijdelijk, in dit soort banen werkzaam zijn.

\section{Onderzoeksopzet}

Duidelijk is dat een relatief nieuwe sector als de callcenterbranche volledig ontbreekt in alle relewante CBS-statistielken. Hierdoor is er weinig up-to-date informatie beschikbaar over de personeels- en arbeidsmarktontwikkelingen in de sector (zie ook Konijn et al., 2002 |, hetgeen ook de ontwikkelingen van de arbeidsverhoudingen op centraal niveau bemoeiliikt. Door het ontbreken van objectieve informatie, kunnen veel sneller interpretatieverschillen tussen sociale partners ontstaan over de ernst of het belang van bepaalde ontwikkelingen c.q. problemen die zich in de sector voordoen.

We hebben geprobeerd deze lacune op te vullen door informatie te vergaren over allerlei aspecten van het werken in de calllcentersector. Ons onderzoek maakt deel uit van het Global Callcenter Industry Project. ${ }^{2}$ Aan dit onderzoeksproject nemen 21 landen deel, te weten Australië, Brazilië, Canada, Dene- marken, Duitsland, Frankrijk, Filippiinen, Groot-Brittannië, Ierland, India, Israël, Japan, Nederland, Noorwegen, Oostenrijk, Polen, Spanje, Verenigde Staten, Zuid-Afrika, ZuidKorea en Zweden. Evenals in de meeste andere landen, bestond het Nederlandse onderzoelk uit twee onderdelen:

- een kwalitatief georienteerd casestudyonderzoek op basis van uitvoerige interviews met verschillende betrokkenen binnen een aantal inhouse en facilitaire callcenters en met vertegenwoordigers van werkgeversorganisaties en vakbonden;

- een enquête onder de managers van inhouse en facilitaire callcenters, waarin kwantitatieve informatie werd verzameld over uiteenlopende aspecten van de personeelsproblematiek, het personeelsbeleid en de arbeidsverhoudingen in het bedriif.

De interviews vonden plaats in een tweetal rondes, in respectievelijk november 2003 en juni 2004. In totaal werden negen callcenters bezocht, waarbij telkens met de algemeen manager, een HRM-manager, een IT-manager en een teamleider of supervisor werd gesproken. De zes inhouse callcenters waren verspreid over verschillende sectoren, zoals telecommunicatie, bank- en verzekeringswezen, automotive en de publieke sector. De drie facilitaire callcenters richtten zich op algemene klantcontacten of leverden juist zeer specialistische diensten, zoals het verzorgen van een IT-helpdesk. Behalve de interviews met de callcenters zijn er uitgebreide gesprekken gevoerd met vertegenwoordigers van de so. ciale partners in de callcentersector, dat wil zeggen met vertegenwoordigers van de vakbond FNV Bondgenoten, de werkgeversvereniging voor de inhouse callcenters VCN en de werkgeversvereniging voor de facilitaire callcenters WGCC. Ten slotte is gesproken met een aantal uitzendbureaus die zich specialiseren in callcenterwerk.

Voor de enquête onder callcentermanagers werd aangesloten bij het NCCBP (Nationaal Contact Center Benchmark Platform)-onderzoek van het ROA uit 2004. Deze benchmarkenquête vindt jaarlijks plaats - in 2004 voor de zevende keer - en kon in de periode april tot en met juli 2004 schriftelijk ingevuld en opgestuurd worden. In totaal leverde dit een 
respons op van 116 managers. Aan deze managers werd vervolgens in september 2004 een korte aanvullende enquête gestuurd; hierop reageerden 50 respondenten. De managers die aan deze aanvullende enquète deelnamen, ziin representatief voor de gehele responsgroep wat betreft het soort callcenter waar ze werkzaam zijn (inhouse of facilitair) en de callcentersector. Wel blijken meer managers van kleine callcenters aan de aanvullende enquête te hebben deelgenomen dan managers van grote callcenters.

\section{De Nederlandse callcenterbranche}

Callcenters zijn organisaties of organisatieonderdelen die gericht zijn op het onderhouden van niet-fysieke klantcontacten, bijwoorbeeld via de telefoon, internet, fax of post. Uit onze encuête blijkt dat $28 \%$ van het totale aantal callcenters in Nederland getypeerd kan worden als een facilitair callcenter, dat de klantcontacten van andere bedrijven verzorgt. De inhouse callcenters zijn verdeeld over verschillende sectoren en zijn vooral terug te vinden in de detailhandel, media en toerisme. (25\%) en de financiële dienstverlening $(19 \%)$. Andere sectoren met veel inhouse callicenters. zijn telecommunicatie, zakelijke dienstverlening en IT (15\%) en de publieke sector loverheden, politie, e.d.) en nutsbedrijven $(13 \%)$.

Er is een groot verschil tussen de aard van de gesprekken in inhouse en facillitaire callcen. ters. Van de inhouse callcenter's verzorgt $94 \%$ met name zogenaamde inbound calls op initiatief van de klanten zelf bijwoorbeeld over informatievragen, aankopen, klachten e.d.). Dit geldt slechts voor $34 \%$ van de facilitaire callcenters. Daar staat tegenover dat $38 \%$ van de facilitaire callcenters vooral outbound calls voert, waarbij het callcenter de Ipotentiële) klanten zelf belt. Van de facilitaire callcenters voert $59 \%$ met name verkoopgesprekken; voor de inhouse callcenters is dit percentage slechts 13 . Bij $86 \%$ van de inhouse callcenters gaan de meeste gesprekken over klantenservice.

De grootste groep medewerkers (agents) in callcenters zijn degenen, die de contacten met de klanten onderhouden. Gemiddeld werken in facilitaire callcenters 290 werknemers, tegenover 127 in inhouse callcenters. Tevens is er in de facilitaire callcenters meer toezicht: zo is er gemiddeld één teamleider op iedere elf medewerkers. Bij de inhouse callcenters is een teamleider verantwoordelijk voor gemiddeld vijftien medewerkers. Wanneer we naar het personeelsbestand van de callcenters kijken, dan blijkt dat er in facilitaire callcenters beduidend meer jongeren werkzaam zijn dan in inhouse callcenters. Zo is 39 procent van de werknemers in facilitaire callcenters jonger dan 25 jaar; bij de inhouse callcenters is dit slechts 24 procent. Ook werken er meer hoger opgeleiden bij facilitaire callcenters: 24 procent heeft een hbo- of universitaire studie tegenover 15 procent in inhouse callcenters. Dit laatste zou kunnen samenhangen met de specifieke werkzaamheden die vaak door de facilitaire callcenters worden verricht, zoals het verzorgen van een IT-helpdesk. Ook kan het gaan om studenten die nog bezig zijn met hun opleiding, of mensen die na hun studie, ter overbrugging naar een beter bij hun studie aansluitende baan, tijdelijk bij een callcenter gaan werken.

\section{Een gesegmenteerde arbeidsmarkt?}

In deze paragraaf zullen we ingaan op de vraag in hoeverre er in de callcenterbranche sprake is van een duale arbeidsmarkt, met de betere banen in de inhouse callcenters en de slechtere banen in de facilitaire callcenters. Overigens, wanneer er op de arbeidsmarkt voor calllcentermedewerkers sprake is van een duidelijke dichotomie in de aangeboden banen, dan betekent dit niet dat de betere banen in de inhouse callcenters automatisch getypeerd kunnen worden als een primaire arbeidsmarkt. Ook de medewerkers in deze callcenters hebben immers vaak slechts een beperkte binding met de arbeidsmarkt. Zo verlaat jaarlijks 11 procent het callcenter, heeft 59 procent een deeltijdaanstelling, en blijkt uit de casestudies dat deze medewer. kers veelal beperkte loopbaanperspectieven hebben. Dit zijn, zoals hiervoor werd aangegeven, typische kenmerken van banen die op de secundaire arbeidsmarkt worden aangeboden Een mogelijke dichotomie tussen de arbeidsmarktpositie van degenen die werken 
in facilitaire callcenters en die in inhouse callcenters, zou dus eerder een indicatie geven van de mate waarin er op het secundaire segment van de arbeidsmarkt sprake kan zijn van een verdere opsplitsing van de arbeidsmarkt. Om hier meer inzicht in te krijgen, zullen we op een aantal punten de arbeidsmarktpositie van agents die werkzaam zijn bij de inhouse callcenters en van agents in facilitaire callcenters in kaart brengen en met elkaar vergelijken. Hierbij kijken we naar de factoren die in de arbeidsmarktsegmentatietheorie gezien worden als indicatoren voor een secundaire arbeidsmarkt. Eerst kijken we naar het gemiddelde uurloon, de secundaire arbeidsvoorwaarden, de arbeidsomstandigheden, de scholingsparticipatie en de doorgroeimogelijkheden. Daarna gaan we in op de indicatoren die samenhangen met de flexibiliteitbehoefte van de callcenters: parttime functies, tijdelijk werk en het personeelsverloop.

In tabel 1 is te zien dat het gemiddelde uurloon van medewerkers in facilitaire callcenters ruim $17 \%$ lager is dan dat van medewerkers in inhouse callcenters. Ook zijn er grote verschillen in de secundaire arbeidsvoorwaarden. Terwijl alle inhouse callcenters pensioenvoorzieningen hebben, is dit slechts bij $39 \%$ van de facilitaire callcenters het geval. Vrijwel alle inhouse callcenters bieden hun medewerkers een spaarloonregeling aan, tegenover slechts $54 \%$ van de facilitaire callcenters. Bovendien dekken inhouse callcenters veel vaker de WAO-risico's af dan de facilitaire callcenters.

Niet alleen de arbeidsvoorwaarden, ook de arbeidsomstandigheden zijn minder goed in facilitaire callcenters dan in inhouse callcenters. Zo is er in de facilitaire callcenters veel minder vaak een formeel arbobeleid, hoewel de verschillen met de inhouse callcenters hier wat minder groot zijn. Dit weerspiegelt zich ook in de concrete verschillen in werkplekfaciliteiten. Zo hebben medewerkers in facilitaire callcenters gemiddeld kleinere werkplekken en minder vaak een in hoogte verstelbaar bureau en airconditioning op hun werkplek. Ook hebben facilitaire callcenters minder vaak 'flatscreens' voor al hun medewerkers. Daarentegen zijn er in de facilitaire callcenters wel iets vaker afscheidingswanden tussen de werkplekken.

Uit tabel 2 blijkt dat facilitaire callcenters tevens veell minder investeren in de intredescholing van hun medewerkers. De facilitaire callcenters trekken hier gemiddeld slechts $€ 1.877$ voor uit, tegenover $€ 5.783$ bij de inhouse callcenters. Dit verschil is ook te vinden in het aantal trainingsuren dat de intredescholing in beslag neemt. In facilitaire callcenters worden medewerkers die outbound

Tabel 1 Arbeidsvoorwaarden en arbeidsomstandigheden van werknemers ("agents') in dienst van inhouse callcenters en werknemers in facilitaire callcenters (NCCPB, 2004)

$\begin{array}{ll}\text { Inhouse } & \text { Facilitair } \\ \text { callcenter } & \text { callcenter }\end{array}$

\section{Primaire arbeidswoorwaarden}

Gemiddeld uurloon

Secundaire arbeidsvoorwaarden

Pensioenwoorziening

Reiskostenvergoeding

Spaarloonregeling

Afdekken WAO-risico

\section{Arbeidsomstandigheden}

Formeel arbobeleid

Gemiddelde omvang werkplek

Scheidingswanden

Verstelbare bureauhoogte

Airconditioning

Flatscreens voor alle werknemers
613,80

11,40

$100 \%$

$97 \%$

$97 \%$

$83 \%$

$39 \%$

$96 \%$

$54 \%$

$35 \%$

$\begin{array}{ll}94 \% & 78 \% \\ 7.5 \mathrm{~m}^{2} & 6,5 \mathrm{~m}^{2} \\ 66 \% & 69 \% \\ 84 \% & 69 \% \\ 84 \% & 69 \% \\ 48 \% & 29 \%\end{array}$


Tabel 2 Scholingsparticipatie van werknemers ('agents') in dienst van inhouse callcenters en werknemers in facilitaire callcenters (NCCPB, 2004)

$\begin{array}{ll}\text { Inhouse } & \text { Facilitair } \\ \text { callcenter } & \text { callcenter }\end{array}$

Intredescholing

Cemiddelde investering in intredescholing

$€ 5.783$

E 1877

Gemiddeld aantal trainingsuren in 2003 :

- outbound werknemers

85 uur $\quad 18$ uur

- irbound werknemers

83 uur

33 uur

Aanvullende scholing

Gemiddeld aantal trainingsuren in 2003:

- outbound werknemers.

20 uur

21 uur

- inbound werknemers

43 uur

25 uur

gesprekken voeren gemiddeld sllechts 18 uur getraind voordat ze productuef worden ingezet. Bij inhouse callcenters ligt het aantal trainingsuren van medewerkers die deze outbound gespreken voeren op een veel hoger niveau: gemiddeld 85 uur.

De veel klleinere groep medewerkers die bij de facilitaire callcenters inbound gesprekken (waaronder de IT-helpdesk) voert, kriggt weliswaar iets meer intredetraining (33 uur), maar ook dit is veel minder dan medewerkers die een vergelijkbare functie hebben bij een inhouse callcenter. Ook zijn er grote verschillen in de mate waarin medewerkers na hun intredescholing nog aanvullende cursussen en trainingen volgen. Zo volgden de meer ervaren inbound medewerkers in de facilitaire callcenters in 2003 gemiddeld slechts 25 uur aanvullende scholing, terwijl de inbound medewerkers die werkzaam waren bij een inhouse callcenter 43 uur training volgden. Daarentegen is er vrijwel geen verschil in het aantal uren dat outbound medewerkers worden getraind: 21 uur in facilitaire callcenters tegenover 20 uur in inhouse callcenters. Waarschijnlijk is het relatief hogere antal trainingsuren van outbound medewerkers in facilitaire callcenters het gevolg van de wisselende bedrijven waarvoor men moet werken, waardoor medewerkers telkens weer nieuwe informatie moeten verwerven over het bedrijf, het product en de specifieke verkoopactie warvoor ze worden ingezet.

Uit de gesprekken die we hebben gehouden met verschillende betrokkenen in callcenters, blijkt dat de carrièreperspectieven van medewerkers in zowel inhouse als facilitaire callcenters zeer beperkt zijn. Doorgroeimogelijkheden binnen het callcenter zijn er eigenlijk alleen naar de functie van teamleider of supervisor. In theorie zijn carrières naar hogere managementfuncties mogelijk, maar deze worden in de praktijk slechts zelden door medewerkers doorlopen. Voor medewerkers die in de inhouse callcenters werkzaam zijn, bestaat wel de mogelij/kheid in een ander onderdeel van de organisatie te gaan werken. Zo kunnen medewerkers die in een callcenter voor een bank werken, overstappen naar een filiaal van deze bank en daar een carrière opbouwen. Vooral voor jonge mensen zonder ervaring in het bankwezen kan het werk bij een callcenter een eerste stap in hun carrière zijn, omdat ze veel sector- en bedriffsspecifieke kennis en valardigheden in het callcenter kunnen opdoen.

\section{Flexibiliteit}

Drie belangrijke indicatoren van een secundaire arbeidsmarkt hangen sterk samen met de grote flexibiliteitbehoefte van de callcenters: het werken met veel parttimers en tijdelijk personeel en een hoog personeelsverloop. In de eerste plaats is het werken met parttimers voor veel. callcenters een belangrijk middel om te kunnen beschikken over een flexibel personeelsbestand, waarmee pieken in het gespreksvolume gedurende de week of werkdag kunnen worden opgevangen. Tabel 3 laat zien dat bij de inhouse callcenters maar 
liefst 59 procent van de medewerkers een deeltijdaanstelling heeft. Bij de facilitaire callcenters ligt het percentage deeltijders echter nog hoger: 77 procent van de medewerkers in deze callcenters werkt parttime. Het grote aantal medewerkers met een deeltijdaanstelling is overigens een belangrijk concurrentievoordeel voor de Nederlandse callcenters ten opzichte van callcenters in andere landen, waar met name vrouwen met een werkende partner veel minder vaak op zoek zijn naar een deeltijdbaan. Zo heeft in Duitsland maar 43 procent van de medewerkers een deeltijdaanstelling (Holtgrewe, 2005), terwijl dit percentage in de VS slechts 16 bedraagt (Batt et al., 2005). Het grote aanbod van deeltijdwerkers in Nederland is ook een van de redenen waarom nogal wat callcenters die een Europese markt bedienen in Nederland zijn gevestigd. ${ }^{3}$

Om fluctuaties in de bedrijvigheid in de loop van het jaar op te vangen, trekken callcenters vaak ook tijdelijk personeel aan. Daarbij worden meestal uitzendbureaus ingeschakeld. In $61 \%$ van de inhouse callcenters en in $74 \%$ van de facilitaire callcenters is tijdelijk personeel werkzaam dat in dienst is bij een uitzendbureau (zie tabel 3). Ook hierin onderscheiden de Nederlandse callcenters zich van de callcenters in andere landen. In bijvoorbeeld Duitsland werkt slechts $15 \%$ van de callcenters met uitzendpersoneel (Holtgrewe, 2005). Dat Nederlandse callcenters zoveel gebruikmaken van uitzendkrachten hangt overigens mede samen met de relatief sterke arbeidsmarktpositie van uitzendkrachten in Nederland. Zo maakt de CAO voor uitzendkrachten het mogelijk uitzendkrachten voor langere tijd aan het uitzendbureau te verbinden. Het is zelfs mogelijk dat een witzendkracht bij het uitzendbureau een contract voor onbepaalde tijd heeft. Door deze relatief goede arbeidsvoorwaarden kunnen uitzend. bureaus veel grotere aantallen uitzendkrachten, die goed inzetbaar zijn als callcentermedewerker, bemiddelen dan in andere landen. Hoewel de kosten voor uitzendwerk door de sterkere arbeidsmarktpositie van de uitzendkrachten hoger zijn dan wanneer het callcenter zelf tijdelijk personeel zou aantrekken, is het aanstellen van uitzendkrachten voor callcenters erg aantrekkelijk. Een callcenter kan hierdoor immers zeer direct en efficiënt inspelen op de fluctuaties in de omzet, zonder dat de werklast en daarmee de productiviteit van de individuele medewerkers daalt. Bovendien wordt men nu op geen enkele manier met ontslagkosten geconfronteerd.

De meeste callcenters werken dan ook met uitzendkrachten. In totaal makt $66 \%$ van de inhouse callcenters bij de werving van personeel gebruik van de diensten van een uit-

Tabel 3 Flexibiliteit van werknemers ("agents") in dienst van inhouse callcenters en werknemers in facilitaire callcenters (NCCPB, 2004)

\section{Inhouse}

callcenter

Deeltijdwerk

Percentage parttimers

\section{Uitzendbureaus}

Percentage callcenters met uitzendkrachten

Percentage callcenters dat rekruteert via uitzendbureaus

Geniddeld percentage uitzendkrachten

Gemiddelde duur van uitzendperiode

\section{Wervingsproblemen}

Percentage callcenters met wervingsproblemen

\section{Personeelsverlloop ( $\%$ jaarlijks)}

Vriwillig

Beëindiging contract of antslag

Totaal verloop
Facilitair

callcenter 
zendbureau. Bij de facilitaire callcenters geldt dit zelfs voor $79 \%$ van de callcenters. Van alle medewerkers die bij een inhouse callcenter werken heeft 16 procent een anstelling bij een uitzendbureau. Bij de facillitaire callcenters is dit percentage overigens nog hoger: maar liefst 25 procent van de medewerkers die bij deze callicenters werkzaam zijn, hebben een uitzendcontract. Gemiddeld werken uitzendkrachten 9,4 maanden bij het inhouse callcenter war ze worden gedetacheerd. Bij de facilitaire callcenters is de gemiddelde tewerkstellingsdurur veel korter: 6,6 maanden.

Zeer kenmerkend voor de positie van de uitzendkrachten in. Nederland is ook dat een deel van dit tijdelijke personeel uiteindelijk in vaste dienst treedt bij het callcenter waar men werkzaam is. Gemiddeld is dit voor een derde van de uitzendkrachten het geval. De relatie tussen callcenters en uitzendbureaus is dan ook vaak erg hecht. Veel callcenters werken samen met een of twee 'dedicated" uitzendbureaus, die de callcenters behalve het uitlenen van tijdelijke arbeidskrachten een uitgebreide dienstverlening aanbieden met betrekking tot de werving en selectie van personeel en de training van de medewerkers. Callcenters shuiten vaak een contract met de uitzendbureaus, waarin afspraken gemaakt worden over het aantal an te leveren uitzendkrachten binnen een bepaalde termijn, op basis van een gedetailleerd profiel waaraan de door het uitzendbureau geselecteerde uitzendkrachten moeten voldoen. Het uitzendbureau test de sollicitanten dan ook waak eerst op hun typevaardigheden en hun communicatieve vaardigheden. Uitzendbureaus die zich specialiseren in callcenterwerk zorgen valk ook voor de vereiste aanvullende scholing. Het gaat dan veelal om basistrainingen in gesprekstechnieken en klantenservice.

De grote rol die uitzendbureaus in de callcenterbranche spelen, hangt voor een deel ook samen met het karakter van het arbeidsmarktsegment waar de callcenters een belangriik deel van hun personeel werven. Men is vaak op zoek naar mensen die in deeltijd willen werken en op het aanbod van een tijdelijke functie willen ingaan. Daarom is het voor veel callcenters, ondanks de momen- teel ruime arbeidsmarkt, waak moeilijk on nieuw personeel aan te trekken. Maar liefst $30 \%$ van de inhouse callcenters heeft op dit punt problemen. Bij de facilitaire callcenters is dat zelfs bij $53 \%$ het geval.

Het grote aantal uitzendkrachten in de callcentersector hangt mogelijk ook samen met het hoge ziekteverzuim onder die medewerkers die langer in een callcenter werkzaam zijn. Dit hoge ziekteverzuim is voor een deel gerel.ateerd aan het stressvolle callcenterwerk en de - vooral op de lange duur - vaak ook fysiek belastende arbeidsomstandigheden. Het ziekteverzuim is het hoogst onder medewerkers in de inhouse callcenters. In deze callcenters gatat hierdoor maar liefst $10,2 \%$ van de totale werktijd verloren. In de facilitaire callcenters bedraagt het ziekteverzuim gemiddeld $9,1 \%$. Bij de medlewerkers die als uitzendkracht in een callcenter werkzaam zijn, ligt het ziekteverzuim op een substantieel lager niveau. Met name bij de inhouse callcenters is het verschil met de medewerkers die in vaste dienst zijn groot: $6,5 \%$ ten opzichte van $10,2 \%$. Bij de facilitaire callcenters is het verschil kleiner: $7,5 \%$ ten opzichte van $9,1 \%$.

De dichotomie in de arbeidsmarktpositie van medewerkers komt ten slotte ook duidelijk tot niting in het personeelsverloop. Hoewel het personeelsverloop in inhouse callcenters, in vergelijking met andere bedrijfssectoren, reeds op een erg hoog niveau ligt $(11 \%$ in 2003) - hetgeen angeeft dat hier reeds sprake is van een secundaire arbeidsmarkt (zie Bergeijk \& De Grip, 1985) - is er in de facilitaire callcenters zelfs een personeelsverloop van maar liefst $19 \%$. Het werschil in het personeelswerloop tussen de facilitaire en inhouse callcenters heeft zowel betrekking op het zogenaamde 'vrijwillig verloop' als op gedwongen verloop (beëindiging arbeidscontract of ontslag]. Bij de facilitaire callcenters is het vrijwillige verloop $8 \%$, tegenover $4 \%$ bij de inhouse callcenters; het gedwongen verloop is respectievelijk $11 \%$ en $7 \%$. Zowel het hoge gedwongen, als het hoge vrijwillige verloop onder medewerkers van facilitaire call. centers, wijst op een geringe binding tussen medewerkers en het bedrijf waar ze werk. zaam zijn. 
- De hierboven beschreven verschillen tussen medewerkers die in een facilitair callicenter werken en medewerkers die werkzaam zijn bij een inhouse callcenter, geven een duide. lijke indicatie van een verdere segmentatie van de secundaire arbeidsmarkt binnen de callcenterbranche. Dit sluit overigens niet uit dat een beperkt deel van de medewerkers die in dienst zijn van een inhouse callcenter een baan heeft op het primaire segment van de arbeidsmarkt. Uit de casestudies blijkt dat dit vooral het geval is bij de inhouse callcenters van multinationale bedrijven in het bankwezen en de automotive sector.

De arbeidsmarktsegmentatie binnen de inhouse callcenters is namelijk sterk verweven met de segmentatie van de klanten van het callcenter, waarbij de belangrijke klanten te woord worden gestaan door beter gelkwalificeerde medewerkers. Uit onderzoek van Batt (2001) blijkt dat dit vooral het geval is bij de dienstverlening aan grote bedrijven. Uit onze gesprekken met een grote bank blijkt dat deze over twee aparte callcenters beschikt: een voor zakelijke klanten en een voor particuliere klanten. De medewerkers van het callcenter voor de zakelijke klanten werken vrijwel allemaal fulltime op standaard kantooruren. Zij zijn goed geschoold en werken vaak al lange tijd bij de bank. Het callcenter voor de particuliere klanten kent een aparte 'top desk' voor de betere kllanten, waar ze op basis van hun bankrekeningnummer automatisch mee worden verbonden. De medewerkers die bij deze top desk werken zijn eveneens hoog opgeleid en kunnen alle bankdiensten afhandelen. De medlewerkers die de contacten met de andere klanten onderhouden, kunnen slechts een beperkt aantal diensten afhandelen (bijvoorbeeld betalen en sparen) en moeten de klant voor overige diensten doorverbinden met een andere afdeling van het callcenter.

\section{Ontwikkelingen in de arbeidsverhoudingen}

Tot slot willen we in kaart brengen hoe de segmentatie van de arbeidsmarkt van callcentermedewerkers verankerd is in de Nederlandse arbeidsverhoudingen en welke ontwikkelingen zich hier de laatste jaren hebben afgespeeld. Dit laatste is wooral interessant omdat de arbeidsverhoudingen in een relatief jonge sector als de callcenterbranche vanzelfsprekend minder ontwikkeld zijn dan in sectoren die op dit punt reeds een lange traditie hebben. Bovendien hebben callcenters vaak de mogelijkheid zich te vestigen op een locatie waar hun ondernemerswrijheid zo min mogelijk aan banden wordt gelegd. Voor zover callcenters zich richten op de Nederlandse markt, is het echter vaak moeilijk om naar een ander land uit te wijken ${ }^{4}$ al zijn er enkele bedrijven die hun callcenter naar ZuidAfrika verplaatst hebben. Daarnaast zijn er echter ook meertalige callcenters die vanuit één land meer Europese landen bedienen. Deze callcenters zullen zich bij voorkeur vestigen in een land waar de arbeidskosten relatief laag liggen en de flexibiliteitbehoefte het best kan worden gerealiseerd. Al moet hierbij wel worden opgemerkt dat het voor deze callcenters minstens zo belangrijk kan zijn dat er op de locatie waar men zich vestigt voldoende mensen werken die de verschillende Europese tallen als moedertaal hebben. Zo zijn er in Maastricht verschillende multilanguage callcenters gevestigd, war reeds in de Euregio wonende Frans, Duits, Italiaans, Engels en Nederlands sprekenden werkzaam zịn.

Zoals in de inleiding al werd aangegeven, vindt het duale karakter wan de arbeidsmarkt voor callcentermedewer|kers zijn oorsprong in de verschillende CAO's waronder de medewerkers vallen. Degenen die werkzaam zijn in inhouse callcenters vallen doorgaans onder de bedrijfs- of bedrijfstak-CAO wanronder het betreffende bedrijf ressorteert. Het betreft meestal CAO's die een lange traditie hebben. Hierdoor zijn de arbeidsvoorwaarden voor de inhouse callcentermedewerkers vaak veel beter dan voor de medewerkers die bij een facilitair callicenter werkzaam zijn. Vanuit het perspectief van de arbeidsverhoudingen zijn de facilitaire callcenters dan ook de nieuwe bedrijfssector, waarvoor een aparte CAO zou kunnen worden overeengekomen.

Beide deelsectoren hebben ook een eigen werkgeversorganisatie. De Vereniging Contactcenters Nederland (VCN) behartigt de belangen wan de inhouse callcenters, terwijl de 
Werkgeversvereniging Callcenters (WGCC) de facilitaire callcenters vertegenwoordigt. Beide werkgeverswerenigingen bestaan overigens nog maar kort. De WGCC werd in 1998 opgericht; de VCN pas in 2003. De WGCC vertegenwoordigt 26 yan de circa 250 facilitaire callcenters in Nederland, waaronder de tien grootste, die goed zijn voor $50 \%$ van de werkgelegenheid in de facilitaire callcenters (Van Klaweren, 20051. De VCN is een organisatie die de positie van de inhouse callcenters binnen het moederbedrijf probeert te versterken en daarnaast probeert de kwaliteit van callcenters te verbeteren door het stimuleren van callcentercertificering en het bevorderen van scholing van medewerkers. De VCN is echter niet betrokken bij CAO-onderhandelingen. Inhouse callcenters vallen immers meestal onder de bedrijfs- of bedrijfstak-CAO van het moederbedrijf. De in 2003 voor het eerst afgesloten CAO voor de callcenterbranche heeft daarom betrekking op de facilitaire callcenters.

De organisatiegraad onder de callcentermedewerkers is zeer laag. Het geringe aantal medewerkers dat vakbondslid is, is te verklaren uit de vaak geringe binding die veel medewerkers met hun werk hebben en het volstrekt ontbreken wan een vakbondscultuur in de meeste callcenters. Bijna alle inhouse callcenters $(96 \%)$ hebben wel een ondernemingsraad, hetgeen ook verplicht is voor bedrijven met meer dan 50 medewerkers. Van de facilitaire callcenters heeft ruim drie kwart een ondernemingsraad. Een vergelijking met onze oosterburen leert dat daar de OR minder ingeburgerd is, vooral bij de facilitaire callcenters. ln Duitsland heeft namelijk $70 \%$ van de inhouse callcenters een ondernemingsraad, en slechts $23 \%$ van de facilitaire callcenters [Holtgrewe, 2005).

Het is interessant om te zien dat een betrekkelijk nieuwe sector als de callcenterbranche, waarvan het personeel bovendien werkzaam is binnen het secundaire segment van de arbeidsmarkt, toch begint te assimileren in het Nederlandse poldermodel. In tegenstelling tot de meeste andere landen werd in 2003 de eerste CAO voor de facilitaire callcenters afgesloten tussen de WGCC en FNV Bondgenoten. Deze CAO werd voorafgegaan door de bedrijfs-CAO van SNT, het grootste facilitaire callcenter van Nederland |zie ook Van Klaveren, 2005). Dit callcenter is een werzelfstandigd onderdeel van $\mathbb{K P N}$ en kent als voormalig overheidsbedrijf een hogere organi. satiegraad onder de medewerkers. Het is overigens opmerkelijk dat de vakbondsonderhandelingen voor deze bedrijfs-CAO nog siteeds gevoerd worden door de ABVAKABO FNV.

De eerste sector-CAO voor de facilitaire call. centers had slechts betrekking op een aantal elementaire arbeidswoorwaarden: proeftijd, omvang werkweek, salaris, wakantiedagen en bijzonder verlof, overwerkvergoeding, ziekte. geld en reiskosten. De drijfveer voor de werk. gevers om deze CAO af te sluiten was de wens om de sector te professionaliseren, er hiermee het imago wan het werk in de call. centers te verbeteren en de wervingsproble. matiek en het personeelsverloop van de call centers terug te dringen. Ook het algemeer verbindend verklaren van $\mathrm{CAO}^{\prime} s$ ir Nederland bliilkt voor werkgevers een motiel te zijn geweest voor het afsluiten van de CAC voor facilitaire callcenters. In ons onderzoek onder callcentermanagers hebben we gevraagd of de CAO voor de facilitaire call. centers tot hogere arbeidskosten geleid heeft Zoals in tabel 4 te zien is, is dit nauwelijks het geval geweest. ${ }^{5}$ Hieruit kan worder geconcludeerd dat deze eerste CAO vooral als functie heeft gehad het minimumniveau voos de beloning en het aantal vakantiedagen vas te leggen. Het algemeen verbindend verklarer van de CAO beschermt hierdoor de werkge vers die de dienstverlening van hun bedrii willen professionaliseren tegen de concurren tie van wat zij zelf aanduiden als 'cowboybe drijven', die tegen 'afbraakprijzen' hun dienst verlening aanbieden, hetgeen mede verant woordelijk is voor het slechte imago van di sector.

Tabel 4 Percentage facilitaire callcenters dat aangeeft dat de eerste $C A O$ effect heeft gehad op bepaalde arbeidsvoorwaarden in hun organisatie (NCCPB, 2004)

Hoger loon 9

Meer vakantiedagen

Meer bijzonder verlof Hogere toeslagen
4

0

8 
De eerste CAO voor de facilitaire callcenters had weliswaar betrekking op alle medewerkers die voltijds of in deeltijd in dienst waren bij een facilitair callcenter, maar niet op het grote aantal uitzendkrachten. Doordat de CAO voor het uitzendwezen op een aantal. punten beter is voor de medewerkers, ${ }^{6}$ hebben de facilitaire callcenters overigens een prikkel om medewerkers zelf in dienst te nemen. Op deze manier kunnen ze bijvoorbeeld afkomen van de verplichting een toeslag te betallen voor het werken in de avonduren.

De looptijd van de eerste CAO voor de facilitaire callcenters was in mei 2004 verstreken. Pas in mei 2005 is er een nieuwe CAO afgesloten tussen de WGCC en de Bond van Telecompersoneel $(\mathrm{BTP}){ }^{7}$ met een looptijd van 17 maanden. In de nieuwe CAO is naast een loonsverhoging een regeling voor aanvullende loondoorbetaling bij ziekte overeengekomen. Ook is er een nieuw functieniveau opgenomen voor functies met meer complexe werkzaamheden. Daarnaast wordt een certificering van medewerkers, het zogenaamde 'startersbewijs' geïntroduceerd en een protocol ten aanzien van de monitoring van de medewerkers. De beide laatste punten vormen een onderdeel van de beoogde kwaliteitsverbetering van het werken in de callcenterbranche. Ten slotte is afgesproken dat gezamenlijke studies zullen worden verricht naar de mogelijkheden voor een 'branchegewijze invoering van de levensloopregeling' en een 'andere facilitering van arbeidsvoorwaarden'. Daarbij wil men op zoek naar 'meer maatwerk', waarschijnliik in de vorm van een bedrag dat een werknemer naar eigen inzicht kan besteden aan pensioen, kinderopvang, en dergelijke.

De nieuwe CAO geldt op dit moment voor 25 bedrijven, die volgens de WGCC samen $80 \%$ van de markt vertegenwoordigen. De grootste vakbond in de branche, FNV Bondgenoten, distantieerde zich van het CAO resultaat dat tot stand is gekomen nadat eerdere onderhandelingen over de nieuwe $\mathbb{C A O}$ tussen de WGCC en FNV Bondgenoten waren vastgelopen. Desalniettemin is de CAO door het ministerie van Sociale Zaken en Werkgelegenheid algemeen verbindend ver- klaard voor de facilitaire callcenters. Belangrijk strijdpunt in de onderhandelingen over een nieuwe CAO voor de facilitaire call centers was de wens van FNV Bondgenoten om in de CAO afspraken op te nemen over een pensioenvoorziening en een functieclassificatiesysteem. Deze wensen zijn in de huidige CAO niet gerealiseerd.

In de enquête is aan de callcentermanagers gevraagd welke punten zij graag in een toekomstige $\mathrm{CAO}$ zouden willen opnemen. Zoals in tabel 5 te zien is, wil een meerderheid van de managers afspraken opnemen over prestatiebeloning en functiespecifieke scholing. Opmerkelijk genoeg is 43 procent van de managers bereid afspraken op te nemen over een pensioenregeling; terwijl 26 procent hier tegen is. Ook zijn er meer voorstanders dan tegenstanders voor het opnemen van afspraken over kinderopvang en functioneringsgesprekken. Daarentegen zijn er vrijwel geen managers die ervoor voelen om afspraken te maken over een spaarregeling voor scholingsverlof.

Tabel 5 Terreinen van personeelsbeleid die in een toekomstige CAO zouden moeten worden opgenomen volgens callcenter managers (NCCPB, 2004)

\begin{tabular}{lcc}
\hline & $j a(\%)$ & nee (\%) \\
\hline Prestatiebeloning & 63 & 21 \\
Functiespecifieke scholing & 53 & 23 \\
Pensioenen & 43 & 26 \\
Kinderopvang & 39 & 29 \\
Functioneringsgesprekken & 39 & 34 \\
Sparen voor schiolingsverlof & 2 & 51 \\
\hline
\end{tabular}

De huidige CAO-perikelen in de callcenterbranche illustreren dat een nieuwe bedrijfssector, waarvan het personeel bovendien werkzaam is binnen het secundaire segment van de arbeidsmarkt, niet automatisch assimileert in het Nederlandse poldermodel. FNV Bondgenoten ziet een duidelijke parallel tussen de ontwikkeling van de CAO voor de facilitaire callcenters en de eerdere CAO-ontwikkelingen in de uitzendbranche. In de uitzendbranche kostte het 15 jaar om een goede $\mathrm{CAO}$ te ontwikkelen; in de callcentersector zou men dit graag in minder tijd willen realiseren op basis van de lessen die men in de uitzendbranche heeft geleerd. Aan de andere 
kant bliikt uit de ontstaansgeschiedenis van de nieuwe $\mathrm{CAO}$ voor facilitaire callcenters dat werkgevers er ook voor kunnen kiezen met cen branchegerichte werknemersorganisatie in zee te gaan, die primair 'streeft naar goede verhoudingen tussen werkgever en werknemers'.

\section{Conclusie}

Uit verschillende indicatoren blijkt dat de arbeidsmarkt voor callcentermedewerkers voor het overgrote deel getypeerd lkan worden als een secundaire arbeidsmarkt. Er is immers sprake van minder gunstige arbeidsvoorwaarden en arbeidsomstandigheden, een groot aantal deeltijdaanstellingen en tijdelijke contracten en een hoog personeelsverloop. Slechts een beperkt deel van de medewerkers die werkzaam zijn bij een inhouse callcenter, is werkzaam op een primair arbeidsmarktsegment. Vaak gaat het hierbii om medewerkers die zorg dragen voor de dienstwerlening aan belangrijke klanten ('top desk'). Binnen het secundaire segment blijkt er een verdere segmentatie te bestaan tussen de inhouse callcenters, waar de relatief betere banen worden aangeboden, en de facilitaire callcenters waar de arbeidsvoorwarden en arbeidsomstandigheden voor de medewerkers slechter zijn. Ook investeren facilitaire callcenters veel minder in de scholing van hun medewerkers en werken er meer medewerkers met een deeltijdcontract en meer uitzendkrachten. Als gevolg hiervan ligt het personeelsverloop bij de facilitaire callcenters dan ook op een veel hoger niveau dan bij de inhouse callcenters.

Het duale karakter van de arbeidsmarkt voor callcentermedewerkers vindt zijn oorsprong in de verschillende $\mathrm{CAO}^{\prime} \mathrm{s}$ waronder de medewerkers vallen. De medewerkers die werkzaam zijn in een inhouse callcenter vallen doorgaans onder de bedrijfs- of bedrijfstak. $\mathrm{CAO}$ waaronder het betreffende bedriif ressorteert. Daarentegen vormen de facilitaire callcenters een nieuwe bedrijtssector met een eigen $\mathrm{CAO}$. De recente ontwikkelingen in de arbeidsverhoudingen laten zien dat de verankering van een nieuwe sector als de callcenterbranche, waarvan het personeel bovendien werkzaam is op een secundaire arbeidsmarkt in het Nederlandse poldermodel zeker gee automatisch proces is. In 2003 werd er eel eerste $\mathrm{CAO}$ afgesloten voor de facilitaire call centers. Dit was een unieke ontwikkeling in vergelijking met andere landen Waarschijnlijk heeft het algemeen verbinden verklaren van CAO's in Nederland hierbij ees belangrijke rol gespeeld, omdat het de werk gevers die de sector graag verder willen pro fessionaliseren beschermt tegen de concur rentie van 'cowboybedrijven'. De recentelijl afgesloten tweede CAO laat echter een gehee andere dynamiek zien. $\mathrm{Na}$ het vastlopen val de $\mathrm{CAO}$-onderhandelingen tussen de WGCK en FNV Bondgenoten heeft de werkgeverson ganisatie een nieuwe $\mathrm{CAO}$ afgesloten met ee: branchegerichte werknemersorganisatie di het gezamenlijke belang van werknemers e: hun werkgever voorop stelt. Dit laatste ka: zijn eigen dynamiek hebben, zoals ook blijk uit een opmerkelijke clausule in het onder handelaarsakkoord: 'Gelet op het specifiek karakter wan de branche is maatwerk i arbeidsvoorwaarden van groot belang. In da licht zal een onderzoek worden gedaan naa mogelijkheden voor een andere faciliterin van arbeidsvoorwaarden, het zogenaamd Lump sum of total cash systeem Aangenomen mag worden dat de kosten val. dit maatwerk lager liggen dan de kosten va. de traditionele arbeidsvoorwaarden die elder in de Nederlandse economie voorkomen. Di zal het secundaire karakter van de arbeids markt van de medewerkers van de facilitair callcenters versterken, ondanks de inbeddin in de Nederlandse arbeidswerhoudingen.

\section{Noten}

I Bij de geringe doorgroeimogelijkheden gaat he vooral om een verschil met de bedriffintern arbeidsmarkt.

2 Het Global Callcenter Industry Project wer geinitieerd door prof. Rose Batt van Come University, VS en prof. Stephen Wood en Davi Holman van Sheffield University, Groo Brittannie. De Grip Sieben \& Van Jaarsvel (2005) geven een uitgebreid verslag van hi Nederlandse onderzoek.

3 Nederland is bovendien een aantrekkelijk vestigingsplek voor callcenters vanwege d betrouwbare infrastructuur en de anwezighei van een meertalige beroepsbevolking. Nik 
alleen spreken weel Nederlanders meer talen, ook zijn er in de onringende landen genoeg "narive speakers' te winden (NFIA, 2004).

4 Met name in de Verenigde Staten en het Verenigd Koninkrijk hebben nogal wat bedrijven hun callcenter verplaatst naar landen als India of Zuid-Afrika.

5 Royer (2004) concludeert meer in het algemeen dat het algemeen verbindend verklaren van CAO's geem loonopdrijwend effect heeft.

6 Zo kent de CAO woor het witzendwezen, in tegenstelling tot die voor de facilitaire callcenters, een pensioenfonds, een vergoeding voor werk in de avonduren en een afdracht wan een deel van de loonsom woor het opleidingsfonds.

7 De BTP had als CAO-partij eerder al ervaring met callcenters opgedaan bij onder andere de bedriff-CAO van SNT.

\section{Literatuur}

Batt, R. 2001$\}$. Explaining wage inequality in telecommunications services: Customer segmentation, human resource practices and union de. cline. Industrial and Labor Relations Review, 54: 425-449.

Batt, R, V. Doelgast \&. H. Kwon (2005). The U.S. Callcenter Industry 2004. National Benchmarking Report. Ithaca, NY: Comell University.

Bergeiilk, C. van \& A. de Grip (1985). Bestaan en ontwikkeling van interne arbeidsmarkten in Nederland. Sociaal Maandblad Arbeid: 437-451.

Braaksma, R.M. [1998]. Bedrifsleven in beeld: Callcenters. Zoetermeer: EIM

Datamonitor $(2002)$. Callcenter Industry Profile: the Netherlands. New York: Datamonitor.

Deery, $S_{.} \& N$. Kinnie $(2004)$. Callcentres and Human Resource Management. A CrossNational Perspective. Houdmills/New York" Palgrave Macmillan.
Dekker, R, A. de Grip \& I.A.M. Heilke 119961. Arbeidsmarktsegmenten in Nederland. Tifd. schrift voor Arbeidswraagstukken, 12: $338 \times 351$.

Dekker, $\mathbb{R}$, A. de Grip \& J.A.M. Heijke (2002). The effects of training and overeducation on career mobility in a segmented labour market. International fournal of Manpower, 23: 106-125.

Doeringer, P.B. \& M.J. Pione (1971). Intemal labor markets and manpower analysis. Lexington: Heath Lexington Books.

Grip, A. de (1987). Onderwiss en arbeidsmarkt: Scholingsdiscrepanties. Proefschrift Vrije Universiteit Amsterdam.

Grip, A. de I. Hoevenberg \& $\mathbb{E}$. Willems (1997). Atypical Employment in the European Union. International Labour Review: 136: 49.71.

Grip, A. de, I. Sieben \& D. wan Jaarsweld (2005). Employment and Industrial Relations in the Dutch Call Center Sector. ROA-R-2005/4, Maastricht.

Holtgrewe, UI. (2005). Callcenters in Germany. Prelminary findings from the Global Call Centre Project. Duisburg: Essen University.

Hoof J.J. van \&. I. Dronkers (1980). Onderwifs en arbeidsmarkt. Deventer: Wan Loghum Slaterus.

Konijn, R. M. Lugt \& G. Yildiran (2002). Arbeidsmarktradar Facilitaire Callcenters. Den Hag: Ministerie wan Economische Zaken.

NCCBP, Nationaal Contact Center Benchmarlk Platform (2004). WWw.nccbp.nl.

NFIA (2004). Shared Service Centers. Den Hag: Netherlands Foreign. Investement Agency.

Osterman, P. (1982). Employment Structures Within Firms. British fournal of Industrial Relation:s, 20: 349-361.

Royer, M. (2004). De invloed van CAO en AVV op de loonvorming. Tijdschrift voor Arbeidsvraagsitukken, 20: 197-210.

Sieben, I. \& A. de Grip (2003). Competenties en skill gaps van callcenter medewerkers "Tijschrift voor Arbeidsvraogstukken, 19: 34-47. 